\title{
Persistan Anemi Etyolojisinde Nadir Bir Lezyon; Hiperplastik Gastrik Polip
}

\author{
Ramazan Kozan
}

Eren Hastanesi, Genel Cerrahi Kliniği, İstanbul, Türkiye

Ramazan Kozan, Uzm. Dr.

İletişim:

Uzm. Dr. Ramazan Kozan

Eren Hastanesi, Genel Cerrahi Kliniği, İstanbul,

Türkiye

Tel: +902165755877

E-Posta: dr.kozan@hotmail.com

Gönderilme Tarihi : 200 cak 2017

Revizyon Tarihi : 28 Nisan 2017

Kabul Tarihi : : 15 Mayıs 2017
ÖZET

Genellikle asemptomatik olan ve insidental olarak saptanan hiperplastik gastrik polipler bazı nadir komplikasyonlara neden olabilmektedirler. Malign odaklar içerebildikleri gösterilmiş olan bu lezyonlar günümüzde artan endoskopik uygulamalara bağlı olarak daha sık karşımıza çıkmaktadırlar. Bu yazıda kronik gastrointestinal kan kaybına sekonder, dirençli demir eksikliği anemisine yol açan gastrik hiperplastik polip olgusu sunulmuştur. $\mathrm{Bu}$ lezyonun neden olabileceği komplikasyonların göz önünde tutulması, özellikle ileri yaş grubundaki anemi olgularında endoskopik taramanın önem ve önceliğinin vurgulanması hedeflenmiştir.

Anahtar sözcükler: Demir eksikliği, endoskopi, hiper plastik gastrik polip, persistan anemi

\section{A RARE LESION IN ETIOLOGY OF PERSISTENT ANEMIA; HYPERPLASTIC GASTRIC POLYP}

\section{ABSTRACT}

Hyperplastic gastric polyps, which are usually asymptomatically and incidentally detected, can cause some rare complications. These lesions have been shown to contain malignant foci, are more often confronted managed with increasing endoscopic applications. In this article, we present a case of gastric hyperplastic polyp which leads led to a persistent anemia of iron deficiency secondary to chronic gastrointestinal bleeding. We aimed to point out the importance and priority of endoscopic scanning in case of anemia especially in advanced age group and to emphasize the complications that may arise from this lesion.

Keywords: Iron deficiency, endoscopy, hyperplastic gastric polyp, persistent anemia

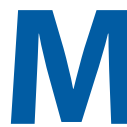
idedenin en sık görülen polipleri olan hiperplastik polipler genellikle asemptomatik olmakla birlikte dispepsi, midede yanma, karın ağrısı ya da anemiye yol açan kanama gibi bulgulara neden olabilirler (1). Gastrointestinal kanamadan şüphelenilen anemik hastalarda hiperplastik gastrik poliplerin önemi tam olarak belirlenememiştir (2). Demir eksikliği anemisi ya da gastrointestinal sistem kanaması şüphesi ile başvuran hastalarda antrumda hiperplastik gastrik polip oranı \%1,4 olarak saptanmıştır (2). Hastalar masif kanama ile başvurabildikleri gibi kronik kan kaybına sekonder anemi ile de seyredebilirler (3). Bununla beraber uzun süre benign patolojiler olarak tanımlanmış olan bu lezyonların displazi ve karsinom odakları içerebildikleri de gösterilmiştir $(4,5)$. Bu yazıda oral demir tedavisine dirençli anemisi olan hastalarda endoskopik incelemenin önemini vurgulamayı ve hiperplastik gastrik poliplerin derin anemiyi de içeren komplikasyonlarına dikkat çekmeyi amaçladık. 


\section{Olgu sunumu}

Altmışyedi yaşında kadın hasta yaklaşık üç aydır olan halsizlik, yorgunluk ve dispeptik şikayetler ile birinci basamak bir sağlık merkezinde değerlendirilmiş. Hemoglobin ( $\mathrm{Hb})$ değeri $6,8 \mathrm{~g} / \mathrm{dL}$ ölçülen hastaya üç ay boyunca günde tek doz $100 \mathrm{mg} \mathrm{Fe}^{+2}$ oral demir tedavisi ve proton pompa inhibitörü verilmiş. Birinci ay kontrol $\mathrm{Hb}$ değeri $7 \mathrm{~g} / \mathrm{dL}$, üçüncü ay değeri $6,9 \mathrm{~g} / \mathrm{dL}$ olarak ölçülen hasta ileri tetkik ve değerlendirme önerisi ile yönlendirilmiş. Tarafımıza başvuran hastanın özgeçmişinde hipertansiyon dışında kronik hastalık öyküsü yoktu. Yapılan değerlendirme ve öyküsünde hematokezya veya melena bulgusu saptanmadı. Fizik muayenesinde vital bulguları normal aralıklarda olan hastada deri ve müköz membranlar soluk olarak gözlendi. Malnütrisyon kliniği bulunmayan ve daha önce hiç transfüzyon yapılmamış olan hastanın yapılan tetkiklerde $\mathrm{Hb}$ değeri $7 \mathrm{~g} / \mathrm{dL}$, hematokrit \%30,1, ortalama alyuvar hacmi 74,2 fL, RDW \%15,9, ferritin $11 \mathrm{ng} / \mathrm{ml}$, serum demiri 14 $\mathrm{mg} / \mathrm{dl}$, total demir bağlama kapasitesi $487 \mathrm{mg} / \mathrm{dl}$ ölçüldü. Vitamin B12 ve Folat düzeyleri ise normal aralıklarda saptandı. Periferik yayma incelemesi hipokrom mikrositer anemi ile uyumluydu. Anti dTG ve anti endomisyum antikorları negatif olan hastaya endoskopik tarama planlandı. Pentax EPK-100p Endoskop (HoyaComp, Tokyo; Japan) ile sedoanaljezi altında üst ve alt gastrointestinal sistem endoskopisi yapıldı. Kolonoskopik incelemede herhangi bir patoloji izlenmezken üst gastrointestinal sistem endoskopisinde antral gastrit ile uyumlu görünüm ve mide antruma lokalize, lümene doğru protrüde, yüzeyi eroziv ve

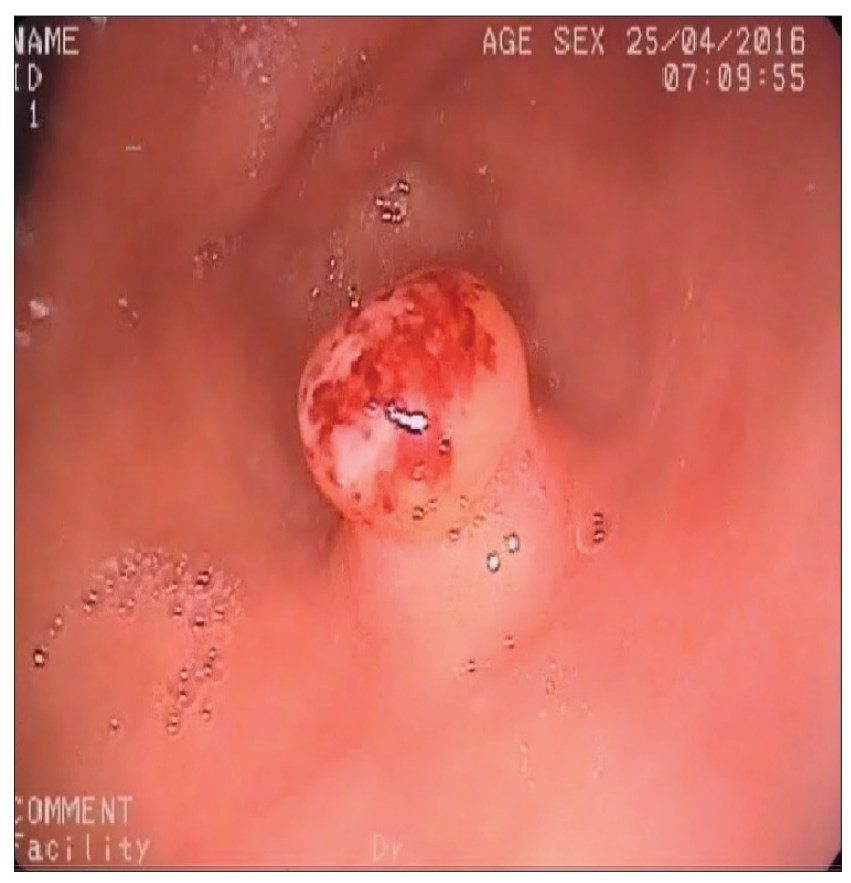

Şekil 1. Antrumda hemorajik gastrik hiperplastik polip. frajil, polipoid lezyon izlendi (Şekil 1). Snare polipektomi yapılarak lezyon tamamen çıkarıldı (Şekil 2). Herhangi bir komplikasyon gelişmeyen hasta bir günlük gözlem sonrası beslenme önerilerinde bulunularak ve medikal tedavisi düzenlenerek tabucu edildi. Takibi süresince transfüzyon yapılmadı. Yapılan patolojik incelemede 1,5x1 cm ölçülerinde, fokal yüzeysel erozyon ve aktif kronik inflamasyon izlenen, Helicobacter pylori açısıdan negatif hiperplastik polip saptandı. Antrum biyopsilerinde kronik gastrit saptanırken çoklu duodenum biyopsilerinde patolojik bulgu izlenmedi. Hastaya altı ay süre ile günde tek doz oral 100 mg Fe ${ }^{+2}$ e eşdeğer Demir (II)-glisin-sülfat-kompleksi tedavisi verildi. Hastanın takibinde üçüncü ay kontrol $\mathrm{Hb}$ değeri $11,3 \mathrm{~g} / \mathrm{dL}$, altıncı ay değeri 12,1 g/dL ölçüldü. Altıncı ay kontrol endoskopik incelemesinde herhangi bir patolojik bulgu saptanmadı. Hastadan tıbbi verilerinin yayınlanabileceğine ilişkin yazılı onam belgesi alındı.

\section{Tartışma}

Gastrik polipler mide mukoza epitelinden kaynaklanan, lümene doğru protrüde, proliferatif veya neoplastik lezyonlardır. Üst gastrointestinal sistem endoskopilerinde gastrik polip insidansı \%0,6 ile \%6 arasında değişmekte olup, otopsi serilerinde bu oran yaklaşık \%1 civarında raporlanmıştır $(6,7)$. Hiperplastik polipler tüm gastrik polipler içerisinde en sık görülen tipdir $(1,8)$. Genellikle asemptomatik olan ve endoskopi esnasında insidental olarak tanı alan bu lezyonlar nadiren de olsa komplike durumlara yol açabilmektedirler. Literatürde gastrik hiperplastik

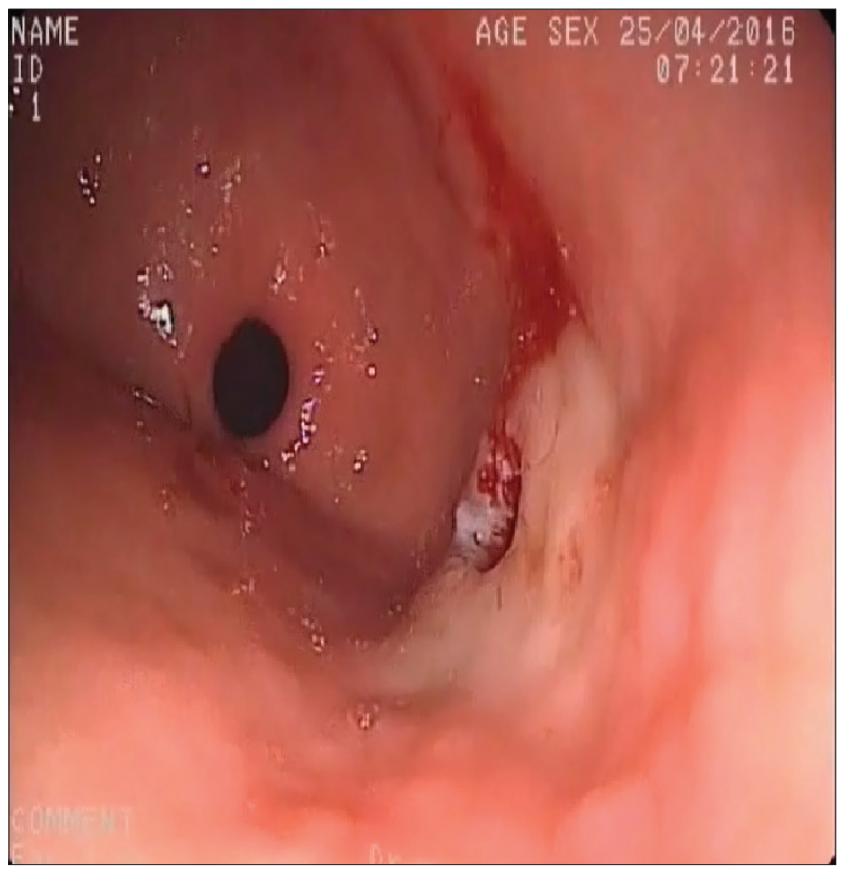

Şekil 2. Snare polipektomi sonrası görünüm. 
poliplerin neden olduğu anemi, kanama, gastrik çıkış obstrüksiyonu, intermittan tıkanma sarılığına sekonder pankreatit olguları tariflenmiştir (9-11).

Demir eksikliği anemisi ya da gastrointestinal sistem kanaması şüphesi ile başvuran 987 hastayı kapsayan bir çaIışmada antrumda hiperplastik gastrik polip oranı \%1,4 olarak sunulmuştur. Bu lezyonlar nadir olsalar da özellikle yaşlı hastalarda görülen gastrointestinal kan kayıplarının önemli bir nedenidirler. Tedavide demir takviyesi ile birlikte bu lezyonların endoskopik veya cerrahi eksizyonu gerekebilmektedir (2).

Klinik pratikte ileri yaş grubundaki demir eksikliği anemisi olgularına yaklaşım daha da önem kazanmaktadır. Gastrointestinal kayıplar demir eksikliği anemisinin en önemli sebepleridir. Etyolojik açıdan premenopozal kadınlarda menstrüel kanamalar ilk sırada yer almasına rağmen postmenapozal kadınlarda en önemli sebep yine gastrointestinal kanamalardır. Üst ve alt gastrointestinal sistem endoskopisinin birlikte uygulanması ile hastaların \%80-85'inde demir eksikliği anemisine sebep olabilecek gastrointestinal bir patoloji saptanabilmektedir (12). Sunduğumuz vakada hiperplastik gastrik polibe sekonder kronik kan kaybına bağlı, dirençli, derin anemi tablosu görülmektedir. Oral demir replasman tedavisine yanıtsız anemi olması üzerine endoskopik inceleme yapılmış, bu sayede hastaya doğru tanı konulabilmiştir. Oysa ileri yaş grubunda demir alımının yetersizliğinden ziyade

\section{Kaynaklar}

1. Jain R, Chetty R. Gastric hyperplastic polyps: a review. Dig Dis Sci 2009;54:1839-46. [CrossRef]

2. Al-Haddad M, Ward EM, Bouras EP, Raimondo M. Hyperplastic polyps of the gastric antrum in patients with gastrointestinal blood loss. Dig Dis Sci 2007;52:105-9. [CrossRef]

3. Nayudu SK, Niazi M, Balar B, Kumbum K. A rare Complication of hyperplastic gastric polyp. Case Rep Gastrointest Med 2013;2013:631975. [CrossRef]

4. Daibo $M$, Itabashi $M$, Hirota $T$. Malignant trasformation of gastric hyperplastic polyps. Am J Gastroenterol 1987;82:1016-25.

5. Markowski AR, Guzinska-Ustymowicz K. Gastric hyperplastic polyp with focal cancer. Gastroenterol Rep 2016;4:158-61. [CrossRef]

6. Carmack SW, Genta RM, Schuler CM, Saboorian MH. The current spectrum of gastric polyps: a 1-year national study of over 120, 000 patients. Am J Gastroenterol 2009;104:1524-32. [CrossRef]

7. Morais DJ, Yamanaka A, Zeitune JM, Andreollo NA. Gastricpolyps: A retrospective analysis of 26,000 digestive endoscopies. Arq Gastroenterol 2007:44:14-7. [CrossRef]

8. Vatansever S, Akpınar Z, Alper E, İpek S, Yazıcıoğlu N, Ekinci N, Unsal B. Gastric polyps and polypoid lesions: Retrospective analysis of 36650 endoscopic procedures in 29940 patients. Turk J Gastroenterol 2015;26:117-22. [CrossRef] gastrointestinal sistemden olan kayıplar daha ön plandadır (13). Bu sebeple özellikle yaşı hastalarda endoskopik tarama daha da öncelikli hal almalıdır.

Hiperplastik polipler ile ilgili bir diğer önemli gerçek de malignite olan ilişkileridir. Oldukça uzun bir süre tamamen benign kabul edilen bu lezyonların displazi ve karsinom içerebilecekleri ya da geliştirebilecekleri ortaya konulmuştur $(4,5)$. Gastrik hiperplastik polipler ile displazi ve karsinom birlikteliği \%1,5-4,5 arasında bildirilmektedir $(1,14)$. Ayrıca polipektomiye kıyasla endoskopik punch biyopsi ile yapılmış histopatolojik örneklemelerin malign odakların tespitinde yetersiz kaldığı da gösterilmiştir (15). Dolaysıyla asemptomatik olgularda bile polipektomi veya endoskopik mukozal rezeksiyonun öncelikli tedavi seçeneği olarak benimsenmesi yönünde bir eğilim oluşmuşur.

Sonuç olarak gastrik hiperplastik polipler malignite potansiyeli taşıyan lezyonlar olup bazı nadir komplikasyonlara yol açabilirler. Bunlardan biri de kronik kan kayıplarına bağlı demir eksikliği anemisidir. Endoskopik inceleme bu hastalarda tanı ve tedaviye olanak sağlaması açısından oldukça değerlidir. Belirgin bir gastrointestinal yakınma veya semptom bulunmasa bile hem yaşa sekonder artmış malignite riski hem de en sık etyolojik faktörün gastrointestinal kayıplar olduğu göz önünde tutularak ileri yaş grubundaki anemik hastalarda endoskopik taramanın demir replasman tedavisine yanıtsızlık beklenilmeksizin yapılmasının uygun olacağı kanaatindeyiz.

9. Yun JT, Lee SW, Kim DP, Choi SH, Kim SH, Park JK, et al. Gastric inverted hyperplastic polyp: A rare cause of iron deficiency anemia. World J Gastroenterol 2016;22:4066-70. [CrossRef]

10. Kosai NR, Gendeh HS, Norfaezan AR, Razman J, Sutton PA, Das S. Prolapsing Gastric Polyp Causing Intermittent Gastric Outlet Obstruction. Int Surg 2015;100:1148-52. [CrossRef]

11. Chahla E, Kim MA, Beal BT, Alkaade S, Garrett RW, Omran L, et al. Gastroduodenal Intussusception, Intermittent Biliary Obstruction and Biochemical Pancreatitis due to a Gastric Hyperplastic Polyp. Case Rep Gastroenterol 2014;8:371-6. [CrossRef]

12. Çoban E, Timurağaoğlu A. Yaşlı hastalarda demir eksikliği anemisine yaklaşım. T Klin J Med Sci 2004;24:267-70.

13. Madej D, Borowska K, Bylinowska J, Szybalska A, Pietruszka B. Dietary intakes of iron and zinc assessed in a selected group of the elderly: are they adequate? Rocz Panstw Zakl Hig 2013;64:97-104.

14. Park DY, Lauwers GY. Gastricpolyps: classification and management. Arch Pathol Lab Med 2008;132:633-40. [CrossRef]

15. Muehldorfer SM, Stolte M, Martus P, Hahn EG, Ell C. Diagnostic accuracy of forceps biopsy versus polypectomy for gastric polyps: a prospective multicentre study. Gut 2002;50:465-70. [CrossRef] 